\begin{tabular}{|c|c|c|}
\hline FALOAK & Jurnal Penelitian Kehutanan Faloak (2021) 5(1), 31-46 & \\
\hline & JURNAL PENELITIAN KEHUTANAN FALOAK & IPK \\
\hline $18=$ & $\begin{array}{l}\text { Akreditasi KEMENRISTEKDIKTI: 10/E/KPT/2019 } \\
\text { http://ejournal.forda-mof.org/ejournal-litbang/index.php/JPKF }\end{array}$ & $\begin{array}{l}\text { e-ISSN } 25795805 \\
\text { p-ISSN } 2620617 X\end{array}$ \\
\hline
\end{tabular}

\title{
STUDI ETNOBOTANI JENIS-JENIS TUMBUHAN BERACUN PADA SUKU DAWAN KECAMATAN FATULEU TENGAH, KABUPATEN KUPANG

\author{
(Ethnobotany study of poisonous plants in Dawan Tribe Fatuleu Tengah Subdistrict, \\ Kupang District)
}

\author{
Arnold Ch. Hendrik ${ }^{1 *}$, Anriyani Ivanita Pinat ${ }^{1}$, dan Apriliana Ballo ${ }^{1}$ \\ ${ }^{1}$ Program Studi Pendidikan Biologi, Fakultas Keguruan dan Ilmu Pendidikan, Universitas Kristen Artha Wacana, \\ Kupang-NTTJ1. Adisucipto PO. BOX 147 Oesapa Kupang
}

\begin{abstract}
Poisonous plants are plants containing a poison that can cause pain or death. The people of the Dawan Fatuleu Tengah tribe have used poisonous plants in their daily lives. However, these types of poisonous plants have not been well documented. The purpose of the present study was to determine the types of poisonous plants and their utilization by the Dawan Fatuleu Tengah tribe. The data collection was conducted by interviewing the respondents for the use of poisonous plants. The obtained results showed that eight types of poisonous plants from six families used by the Dawan Fatuleu Tengah tribe, namely arbila nuts (Phaseolus lonatus L.), tubaroot (Deris elliptica L.), cassava (Manihot esculent), sengon (Paraserianthes faltacataria L.), ginje (Thevetia peruvianan), kecubung (Datura metel L.), ceremai (Phyllanthus acidus L.), and biduri (Calotropis gigantean L.). The Dawan Fatuleu Tengah tribe community uses these poisonous plants to poison fish in the river for consumption, as a natural pesticide, to kill insect disease vectors, and for attacking the enemy.
\end{abstract}

Keywords: Dawan Fatuleu Tengah Tribe, Fatuleu, Pesticide, Toxic plants

\section{ABSTRAK}

Tumbuhan beracun merupakan tumbuhan yang mengandung racun dan dapat menyebabkan rasa sakit atau kematian. Masyarakat suku Dawan Fatuleu Tengah telah lama memanfaatkan tumbuhan beracun dalam kehidupan sehari-hari. Namun, sampai saat ini jenis-jenis tumbuhan beracun tersebut belum terinventarisasi dengan baik. Tujuan dari penelitian ini adalah untuk mengetahui jenis-jenis tumbuhan beracun dan pemanfaatannya oleh suku Dawan Fatuleu Tengah. Teknik pengambilan data berupa pengambilan sampel responden dapat dilakukan dengan menghimpun keterangan melalui wawancara tentang pemanfataan tumbuhan beracun. Hasil penelitian yang diperoleh menunjukkan bahwa terdapat 8 jenis tumbuhan beracun dari 5 famili yang dimanfaatkan suku Dawan Fatuleu Tengah yaitu kacang arbila (Phaseolus lonatus L.), akar tuba (Deris elliptica L.), ubi kayu (Manihot esculenta), sengon (Paraserianthes faltacataria L), ginje (Thevetia peruviana), kecubung (Datura metel L), ceremai (Phyllanthus acidus L), biduri (Calotropis gigantean L). Masyarakat suku Dawan Fatuleu Tengah memanfaatkan tumbuhan beracun tersebut untuk meracuni ikan di sungai untuk dikonsumsi, sebagai pestisida alami, untuk membunuh serangga vektor penyakit, dan juga untuk menyerang musuh.

Kata kunci: Fatuleu, Pestisida, Tumbuhan Beracun, Suku Dawan Fatuleu Tengah

\begin{tabular}{|c|c|c|}
\hline \multicolumn{3}{|c|}{ Article Info } \\
\hline \multirow{2}{*}{\multicolumn{2}{|c|}{$\begin{array}{l}\text { *Corresponding Author } \\
\text { Articel History }\end{array}$}} & Arnold_hendrik@yahoo.co.id (A.C. Hendrik) \\
\hline & & $\begin{array}{l}\text { Received } 7 \text { September 2020; received in revised from } 24 \text { February 2021; accepted } 21 \text { April 2021; } \\
\text { Available online since } 30 \text { April } 2021\end{array}$ \\
\hline \multicolumn{2}{|c|}{ How to cite this article } & $\begin{array}{l}\text { Hendrik, A.C., Pinat, A.I., A., \& Ballo, A. (2021). Studi Etnobotani Jenis-Jenis Tumbuhan Beracun } \\
\text { Pada Suku Dawan Kecamatan Fatuleu Tengah Kabupaten Kupang. Jurnal Penelitian Kehutanan } \\
\text { Faloak, 5(1):31-46. DOI : http://doi.org/10.20886/jpkf.2021.5.1.31-46 }\end{array}$ \\
\hline \multirow[t]{2}{*}{ Read Online } & \multirow{2}{*}{ 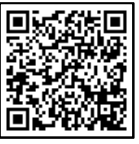 } & $\begin{array}{l}\text { Scan this QR code by } \\
\text { your mobile device }\end{array}$ \\
\hline & & (C)PKF-2021. Open access under CC BY-NC-SA license \\
\hline
\end{tabular}




\section{PENDAHULUAN}

Tumbuhan merupakan sumber daya alam yang penting bagi manusia. Manusia memanfaatkan tumbuhan dalam kehidupan untuk berbagai keperluan, baik yang bersifat mendasar seperti penghasil oksigen, pangan, sandang, dan papan. Tumbuhan juga dimanfaatkan oleh manusia sebagai obat, bahan kerajinan, hiasan baik di dalam maupun di luar rumah, serta bentuk pemanfaatan lainnya termasuk sebagai bahan racun. Tumbuhan dapat digunakan sebagai bahan racun karena tumbuhan mengandung sejumlah zat kimia yang apabila terjadi kontak langsung dengan manusia dan hewan, baik dimakan atau dihirup dengan melebihi kadar yang ditentukan, dapat berakibat sakit atau kematian. Racun alami pada tumbuhan umumnya berada dalam kadar yang rendah, namun beberapa tumbuhan memiliki dosis racun yang bisa mengakibatkan kematian, sehingga butuh pengolahan yang baik untuk menghilangkan kadar racunnya.

Menurut Setiawati et al. (2008), Indonesia diperkirakan mempunyai 50 famili tumbuhan beracun. Tumbuhan yang mengandung bahan beracun dimanfaatkan untuk keperluan yang berbeda oleh masyarakat. Ilmi et al. (2015) menyatakan bahwa tumbuhan beracun dimanfaatkan suku Dayak, Desa Simpang, Kabupaten Barito Kuala untuk berburu, membunuh serangga atau hewan pengganggu. Tumbuhan beracun digunakan pula untuk menyerang musuh. Beberapa tumbuhan penghasil racun alami telah diujikan pada organisme pengganggu tanaman seperti kersen (Muntinga calabura) untuk hama ulat tanah dan ulat grayak, titonia (Tithonia diversifolia) untuk kutu putih, Baringtonia asiarica dan Annona muricata untuk Aphis gossypii serta tumbuhan puar kilat (Globba sp.), sitawar (Costus speciousus), legundi (Vitex trifolia) (Binawati \&
Amilah, 2013; Widyastuti et al., 2018; Salaki \& Pelealu, 2012; Utami \& Haneda, 2010). Masih banyak lagi tumbuhan beracun yang telah dikenal sebagai pestisida alami.

Tumbuhan yang dapat dijadikan pestisida alami umumnya mengandung senyawa-senyawa aktif yang merupakan metabolit sekunder untuk pertahanan dari ancaman organisme pengganggu (Asmaliyah et al., 2010). Senyawa aktif yang dapat berperan sebagai pestisida alami ini umumnya berasal dari golongan senyawa alkaloid, saponin, tanin, flavonoid, polifenol, minyak atsiri (borneol \& sineol), dan beberapa senyawa lainnya. Tanaman oleander (Nerium oleander L.) mengandung senyawa beracun yakni oleandrin dan adinerin yang merupakan golongan alkaloid yang berdaya racun, dan menghambat sistem respirasi (Putri et al., 2019). Daun titonia mengandung senyawa aktif seperti flavonoid, alkaloid, dan tanin yang dapat membunuh dan juga mencegah datangnya organisme pengganggu tanaman (Taofik et al., 2010).

Tumbuhan beracun juga telah lama dikenal masyarakat suku Dawan Fatuleu Tengah Pulau Timor (atoin meto). Pada umumnya tumbuhan beracun ini erat kaitanya dengan pemanfaatan untuk tujuan kriminal seperti menyerang musuh. Kematian mendadak seseorang di kalangan masyarakat pedesaan di Pulau Timor, umumnya diduga akibat diracun melalui makanan atau minuman. Racun ini dipercaya diambil dari sekitar pemukiman yang umumnya berasal dari tumbuh-tumbuhan. Tumbuhan beracun juga dimanfaatkan untuk menanggulangi hama atau binatang pengganggu. Namun demikian, tumbuhan mengandung racun yang dimanfaatkan suku Dawan Fatuleu Tengah sampai saat ini belum terinventarisasi. Oleh karena itu, perlu dilakukan inventarisasi tumbuhan beracun di 
suku Dawan Fatuleu Tengah, sehingga dapat menambah informasi jenis-jenis tumbuhan mengandung racun. Selain itu, dapat menjadi bahan pertimbangan untuk penelitian lebih lanjut terkait bentuk pemanfaatannya, antara lain sebagai bahan pestisida alami.

\section{METODE PENELITIAN}

Penelitian dilaksanakan di Desa Nunsaen dan Desa Nonbaun, Kecamatan Fatuleu Tengah, Kabupaten Kupang, peta lokasi penelitian disajikan pada Gambar 1. Penelitian dilakukan pada bulan Juni 2019. Masyarakat Desa Nunsaen dan Desa Nonbaun didominasi oleh etnis Dawan Fatuleu Tengah, juga beberapa keluarga dari Suku Dawan dari Kabupaten Timor Tengah Selatan.

Metode yang digunakan dalam penelitian ini adalah metode deskriptif kualitatif dengan teknik observasi (pengamatan) langsung dan wawancara semi terstruktur yang mengacu pada daftar pertanyaan. Tahapan yang dilakukan di lokasi penelitian adalah sebagai berikut:

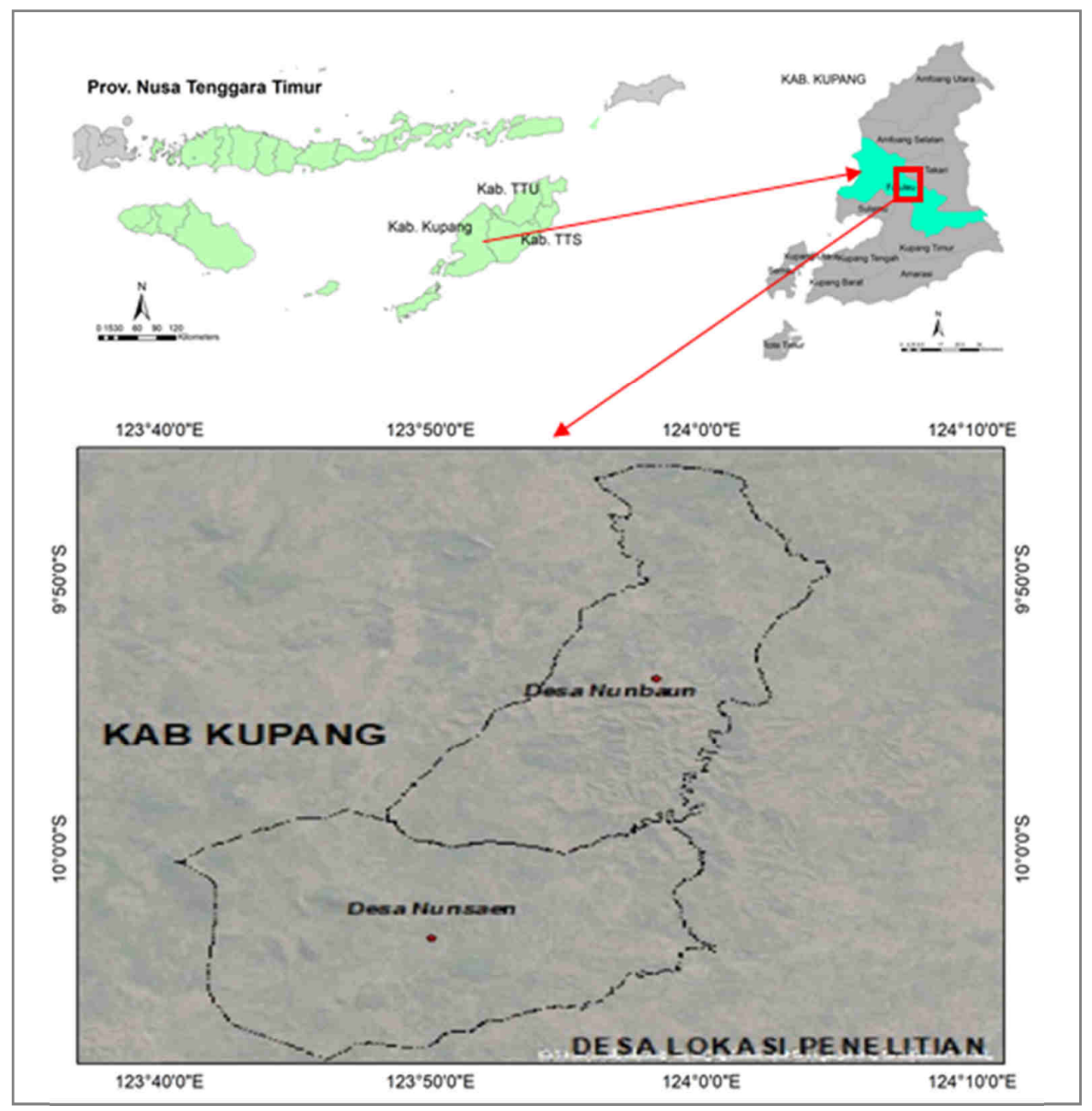

Gambar 1. Lokasi penelitian dan penempatan transek pengamatan (Figure 1. Research location and distribution of transect observation) 


\section{a. Tahap observasi}

Observasi dilakukan dengan mewawancarai Kepala Desa Nunsaen dan Desa Nonbaun. Informasi yang dikumpulkan antara lain adalah calon responden, yaitu tokoh-tokoh masyarakat, tokoh adat, dan masyarakat yang mempunyai pengetahuan terkait tumbuhan beracun. Observasi juga dilakukan untuk mengetahui gambaran umum lokasi penelitian seperti luas desa dan jarak tempat tinggal calon responden. b. Tahap persiapan

Pada tahap ini dilakukan persiapan alat dan bahan yang diperlukan pada saat penelitian. Persiapan dilakukan berdasarkan gambaran umum selama observasi sehingga setiap kebutuhan terlengkapi.

c. Menentukan responden

Responden dipilih dengan menggunakan teknik purposive sampling. Kriteria responden yang digunakan adalah sebagai berikut: a) memahami tentang pemanfaatan jenis-jenis tumbuhan beracun, b) pernah dan sedang memanfaatkan tumbuhan beracun. Berdasarkan kriteria responden dan hasil wawancara dengan kepala desa, tokoh masyarakat, dan tokoh adat, jumlah responden yang dipilih adalah 14 orang dari Desa Nunsaen dan Desa Nonbaun. Responden dipilih berdasarkan informasi hasil wawancara dengan kepala desa, tokoh masyarakat, dan tokoh adat, serta memperhatikan kriteria yang ditetapkan.

\section{d. Melakukan wawancara}

Wawancara dilakukan terhadap responden yang sudah ditentukan untuk mendapatkan informasi tentang jenis-jenis tumbuhan beracun dengan menggunakan bahasa lokal dan bahasa Indonesia. Wawancara bertujuan untuk menggali berbagai jenis tanaman beracun yang dimanfaatkan untuk berbagai tujuan. e. Melakukan Penjelajahan

Tahap ini dilakukan untuk mengetahui keberadaan jenis tanaman yang informasinya telah diperoleh dari hasil wawancara. Pencarian jenis tumbuhan beracun, dilakukan dengan menjelajahi sekitar pekarangan penduduk, kebun dan hutan. Penjelajahan dilakukan bersama-sama dengan responden yang memberikan informasi, sehingga dapat diperoleh tumbuhan yang tepat. Pada kegiatan ini juga dilakukan pengumpulan materi tumbuhan seperti daun, batang, bunga, dan buah untuk diidentifikasi di Laboratorium Pendidikan Biologi, Universitas Kristen Artha Wacana, Kupang.

\section{f. Identifikasi}

Identifikasi jenis tumbuhan beracun dilakukan melalui dua tahapan, yaitu: a) deskripsi morfologi tumbuhan beracun yang ditemukan, dan b) mencocokkan deskripsi ciriciri spesies yang ditemukan di lapangan dengan kunci determinasi spesies baik buku, jurnal ataupun pustaka lainnya yang relevan.

Analisis data dilakukan secara deskriptif kualitatif berdasarkan hasil tabulasi data dalam bentuk tabel.

\section{HASIL DAN PEMBAHASAN}

\section{A. Jenis-jenis Tumbuhan Beracun yang Dikenal oleh Suku Dawan Fatuleu Tengah}

Berdasarkan hasil wawancara, masyarakat suku Dawan Fatuleu Tengah di Kecamatan Fatuleu Tengah mengenal delapan tumbuhan yang mengandung racun. Delapan tumbuhan beracun ini tergolong dalam enam famili, yaitu Fabaceae, Euphorbiaceae, Apocynaceae, Solanaceae, Phyllanthaceae, dan Asclepiadaceae. Jenis-jenis tumbuhan beracun yang ditemukan, bagian yang dimanfaatkan, dan penggunaannya ditampilkan dalam Tabel 1 . 
Tabel 1. Tumbuhan beracun, bagian yang dimanfaatkan, dan penggunaannya Table 1. Poisonous plants, the used parts, and their utilizations

\begin{tabular}{|c|c|c|c|c|}
\hline $\begin{array}{l}\text { No. } \\
(\text { No. })\end{array}$ & $\begin{array}{c}\text { Nama Ilmiah/ } \\
\text { NamaUmum } \\
\text { (Scientific Name / } \\
\text { Common Name) }\end{array}$ & $\begin{array}{c}\text { Nama } \\
\text { Daerah } \\
(\text { Local } \\
\text { Name })\end{array}$ & $\begin{array}{l}\text { Bagian yang } \\
\text { Digunakan } \\
\text { (The used } \\
\text { parts) }\end{array}$ & $\begin{array}{c}\text { Penggunaan racun } \\
\text { (Utilization) }\end{array}$ \\
\hline 1. & $\begin{array}{l}\text { P. lonatus L. / } \\
\text { Kacang arbila hutan }\end{array}$ & Kot laos & Biji & $\begin{array}{l}\text { Menyerang musuh dan } \\
\text { digunakan untuk racun } \\
\text { serangga. }\end{array}$ \\
\hline 2. & $\begin{array}{l}\text { D. eliptica/ } \\
\text { Tuba }\end{array}$ & Tufe & Akar & $\begin{array}{l}\text { Meracuni ikan, udang, belut } \\
\text { dan serangga. }\end{array}$ \\
\hline 3. & $\begin{array}{l}\text { M. esculenta / } \\
\text { Ubi kayu }\end{array}$ & Lauk fua & Daun dan buah & $\begin{array}{l}\text { Meracuni babi dan binatang } \\
\text { hutan di kebun. }\end{array}$ \\
\hline 4. & $\begin{array}{l}P . \text { faltacataria / } \\
\text { Sengon }\end{array}$ & Angka'i & Kulit batang & Meracuni hama dan serangga \\
\hline 5. & $\begin{array}{l}\text { T. peruviana / } \\
\text { inje }\end{array}$ & Tun Mollo & Getah dan buah & Menyerang musuh \\
\hline 6. & $\begin{array}{l}\text { D. metel/ } \\
\text { Kecubung }\end{array}$ & Ko'ma & $\begin{array}{l}\text { Akar, batang, } \\
\text { dan daun }\end{array}$ & Menyerang musuh \\
\hline 7. & $\begin{array}{l}\text { P. acidus / } \\
\text { Ceremai }\end{array}$ & Salmelak & Akar & Menyerang musuh \\
\hline 8. & $\begin{array}{l}\text { C. gigantean / } \\
\text { biduri }\end{array}$ & A'to & Getah & Meracuni hewan pengganggu \\
\hline
\end{tabular}

B. Cara Pengolahan dan Bentuk Pemanfaatan Tumbuhan Beracun oleh Suku Dawan Fatuleu Tengah

\section{Kacang arbila hutan (P. lutantus $\mathbf{L}$.)}

Kacang arbila hutan dikenal masyarakat suku Dawan Fatuleu Tengah dengan nama kot laos. Bagian tumbuhan yang mengandung racun adalah bijinya. Biji dari tanaman ini juga dimanfaatkan suku Dawan Fatuleu Tengah sebagai sumber pangan. Biji kacang arbila hutan digunakan sebagai bahan tambahan untuk masakan berbahan dasar jagung khas suku Dawan Fatuleu Tengah yang dikenal dengan nama 'jagung bose'. Biji kacang arbila oleh suku Dawan Fatuleu Tengah diolah khusus untuk menghilangkan kandungan racunnya, yaitu dengan perebusan sebanyak 12 kali sebelum dicampurkan ke bahan makanan. Setiap perebusan, air sisa perebusan dibuang dan digantikan air baru untuk perebusan selanjutnya. Kacang arbila yang berwarna hitam (Gambar 2), bukanlah satu-satunya kacang arbila yang mengandung racun. Menurut Puspita (2017), dari 11 varietas kacang arbila lokal di Pulau Timor, terdapat 4 kacang arbila beracun yaitu kot laos (arbila beracun), kot metan (arbila hitam), kot molo (arbila kuning), dan kot molmuti (arbila kuning putih). Kacang arbila mengandung racun golongan glikosida sianogenik (linamarin dan phaseolunatin) yang merupakan kelompok racun yang dapat diubah untuk menghasilkan hidrogen sianida $(\mathrm{HCN})$. Kandungan sianida pada kacang arbila bervariasi berdasarkan tingkat kematangan, fase perkembangan, genotipe, dan kondisi tempat hidup. Biji dan daun kacang arbila yang muda lebih banyak mengandung HCN dibandingkan pada kacang arbila yang telah matang fisiologis (Ballhorn, 2005). Menurut Baudoin (2006), kacang arbila liar juga mengandung $\mathrm{HCN}$ lebih 
tinggi dibandingkan kacang arbila yang dibudidayakan. HCN pada kacang arbila sebenarnya merupakan bentuk pertahanan terhadap herbivora. Produksi HCN berkorelasi dengan kehilangan luas daun, semakin banyak kehilangan luas daun, maka produksi $\mathrm{HCN}$ pada kacang arbila akan meningkat (Ballhorn, 2009).

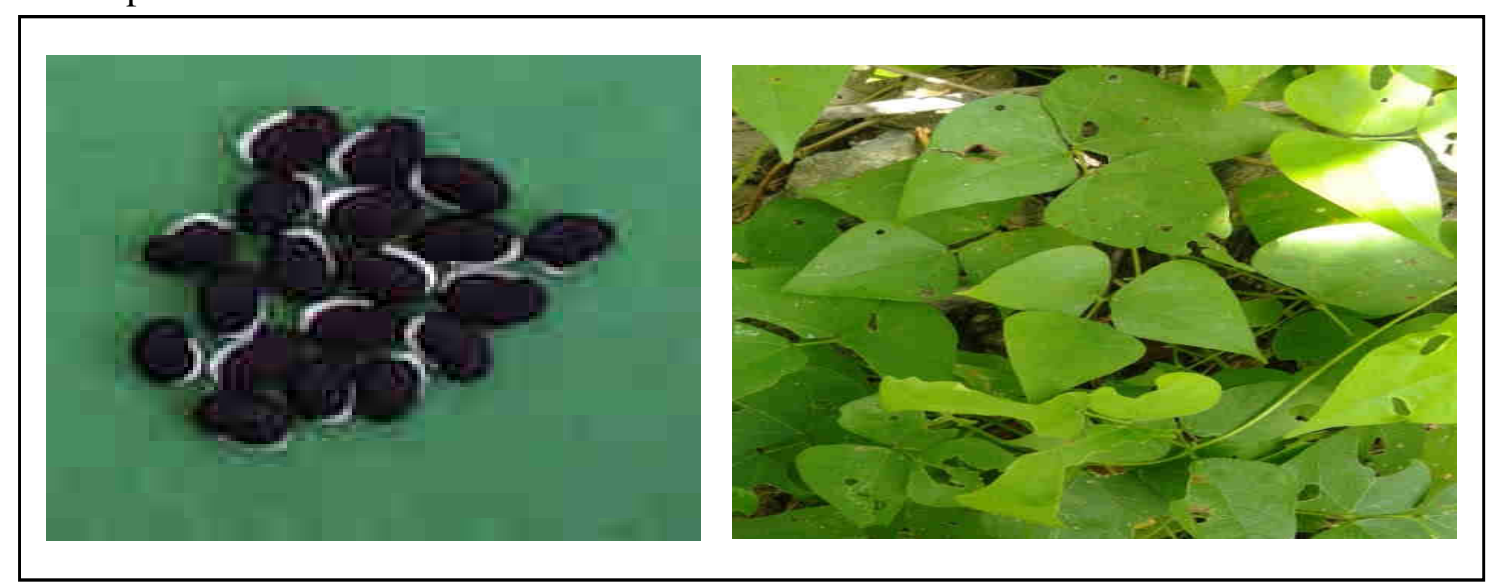

Gambar 2. Ilustrasi pengukuran diameter tajuk (D1 dan D2) Figure 2. Ilustration of crown diameter measurement (D1 and D2)

Menurut masyarakat suku Dawan Fatuleu Tengah, air rebusan pertama biji kacang arbila hutan yang mengandung racun yang mematikan. Perebusan dilakukan selama kurang lebih 30 menit. Racun biji kacang arbila ini dimanfaatkan masyarakat sebagai racun serangga (insektisida). Cara pengaplikasiannya dengan menyemprotkan cairan hasil rebusan tersebut ke serangga seperti lalat dan agas. Air rebusan biji kacang arbila tidak perlu dicampurkan dengan zat kimia lainnya, karena menurut warga, zat racun yang sangat berbahaya ada pada air rebusan pertama tersebut. Takaran air pada saat merebus biji kacang arbila hutan juga tidak terlalu banyak, disesuaikan dengan berapa banyak biji kacang arbila hutan yang akan direbus atau biasanya untuk $1 \mathrm{~kg}$ biji kacang arbila hutan direbus dalam air 3-4 liter.

\section{Tuba (D. elliptica L.)}

Masyarakat suku Dawan Fatuleu Tengah mengenal tumbuhan tuba dengan sebutan tufe (Gambar 3). Tuba atau tufe memiliki banyak manfaat bagi masyarakat suku Dawan Fatuleu Tengah, di antaranya digunakan sebagai racun untuk menangkap ikan, udang, dan belut. Tuba dimanfaatkan pula sebagai pestisida alami serta dijadikan tali pengikat. Tanaman tuba telah dikenal luas pemanfaatannya sebagai racun untuk menangkap ikan, pestisida alami, dan pembunuh serangga vektor penyakit (Asmaliyah et al., 2010; Kinansi et al., 2018; Sumarmin, 2016). Senyawa kimia beracun yang ditemukan pada ekstrak akar tuba, terutama berasal dari golongan flavonoida seperti rotenone, toxicarol, elliptone, sumatrol, tephrosin, dan deguelin (Sayono, 2019). Senyawa aktif rotenone diketahui manfaatnya sebagai bioinsektisida, dan memiliki efektivitas lebih baik dibanding senyawa aktif lain dalam ekstrak akar tuba (Zubairi et al., 2014). Rotenone juga aman dimanfaatkan dalam bidang pertanian maupun penggunaan lainnya, karena rotenone akan kehilangan toksisitas pada 2-3 hari pada musim panas (Sae-Yun et al., 2006). Hal ini dikarenakan rotenone tidak stabil terhadap udara, cahaya dan kondisi alkalin, sehingga mudah rusak pada tanah dan air. 


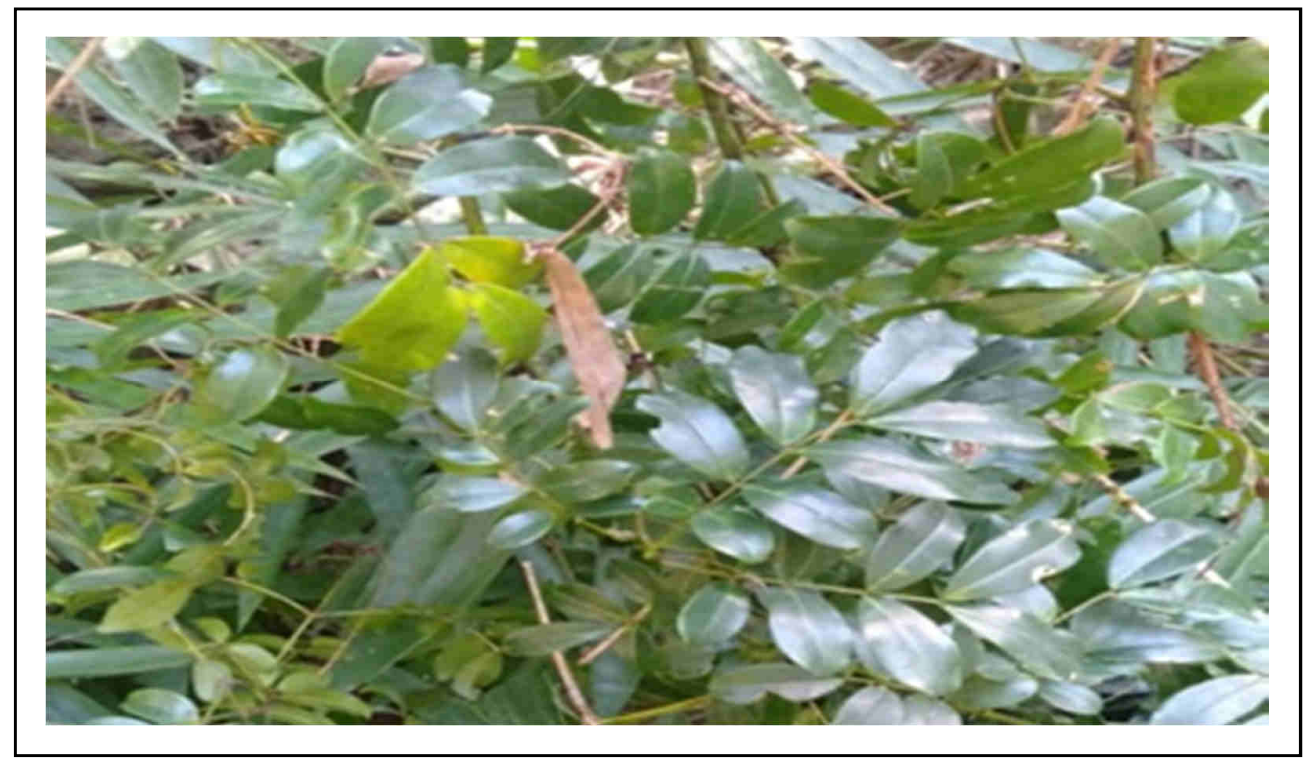

Gambar 3. Tuba (D. elliptica)

Figure 3. Tuba Root (D. elliptica)

Cara pemanfaatan akar tuba sebagai racun ikan oleh masyarakat suku Dawan Fatuleu Tengah yaitu dengan menumbuk akar tuba tetapi tidak sampai putus, kemudian dibawa ke sungai atau bagian air sungai yang telah dibendung, dan direndam selama \pm 12 jam. Hasil yang diperoleh dari rendaman akar tuba tersebut dapat menyebabkan ikan mati. Ikan hasil tangkapan dengan racun tuba, terlebih dahulu dicuci menggunakan air bersih sebelum dikonsumsi. Ikan kemudian dikukus atau direbus dalam air mendidih dengan tujuan agar racun yang terdapat dalam ikan akan hilang dan aman untuk dikonsumsi. Pemanfaatan akar tuba atau tufe sebagai bahan pestisida nabati oleh masyarakat suku Dawan Fatuleu Tengah dilakukan menumbuk dan mememarkan akar tuba, kemudian direndam dalam sawah. Kandungan racun yang ada dalam akar tuba dapat mematikan hama seperti ulat akar, berudu, dan katak kecil. Bentuk pemanfaatan lain akar tuba oleh masyarakat suku Dawan Fatuleu
Tengah adalah sebagai tali pengikat pagar di kebun mereka.

\section{Ubi kayu (M. esculenta Crantz)}

Masyarakat suku Dawan Fatuleu Tengah sering menyebut ubi kayu beracun ini dengan sebutan lauk fua (Gambar 4). Bagian tanaman yang dapat dijadikan racun adalah bagian buah atau biji, sedangkan umbinya dapat dikonsumsi. Masyarakat sering memanfaatkan buah ubi kayu untuk meracuni hewan penganggu tanaman di kebun seperti babi hutan dan anjing. Laporan terkait kandungan racun pada buah ubi kayu sampai saat ini masih terbatas. Okibgo (1980) melaporkan kandungan hidrogen sianida sebesar 7,5 mg/kg biji ubi kayu pahit, sedangkan pada biji ubi kayu manis kandungannya 0 $\mathrm{mg} / \mathrm{kg}$. Ubi kayu manis memiliki kandungan HCN < 40 ppm, sedangkan ubi kayu pahit memiliki kandungan $\mathrm{HCN}>50 \mathrm{ppm}$ (Noerwijati \& Budiono, 2018). Kandungan HCN antar varietas ubi kayu pun berbeda-beda. Pada umbi varietas ubi kayu malang-4 terdapat kadungan HCN $116 \mathrm{mg} / \mathrm{kg}$, varietas adira-4 
sebanyak $63 \mathrm{mg} / \mathrm{kg}$, dan varietas darul hidayah sebanyak 39 mg/kg (Ariani et al., 2017). Montagnac et al. (2008) dan Fasuyi (2005) menyatakan bahwa daun ubi kayu mengandung HCN lebih banyak (600 mg/kg) dari akar ubi kayu (biasanya di bawah $200 \mathrm{mg} / \mathrm{kg}$ ). Ubi kayu mengandung senyawa sianogenik yang dikenal dengan linamarin dan lotaustralin. Yuningsih (2009) menyatakan kadar senyawa HCN pada ubi kayu dipengaruhi oleh varietas ubi kayu, umur tanaman, faktor tanah, kelembaban, temperatur, dan faktor lingkungan lainnya.
Pengolahan buah ubi kayu oleh suku Dawan Fatuleu Tengah dilakukan dengan cara buah diambil dan ditumbuk sampai halus, kemudian dicampur dengan makanan yang disimpan dalam kebun sebagai umpan. Perlu dilakukan pengawasan secara terus menerus sampai binatang target memakan makanan yang telah dicampur racun tersebut. Apabila binatang telah memakan makanan yang telah dicampur dengan racun ubi kayu, maka binatang tersebut akan mengalami kejang-kejang dan beberapa menit kemudian binatang tersebut akan mengeluarkan busa lewat mulut dan mati.

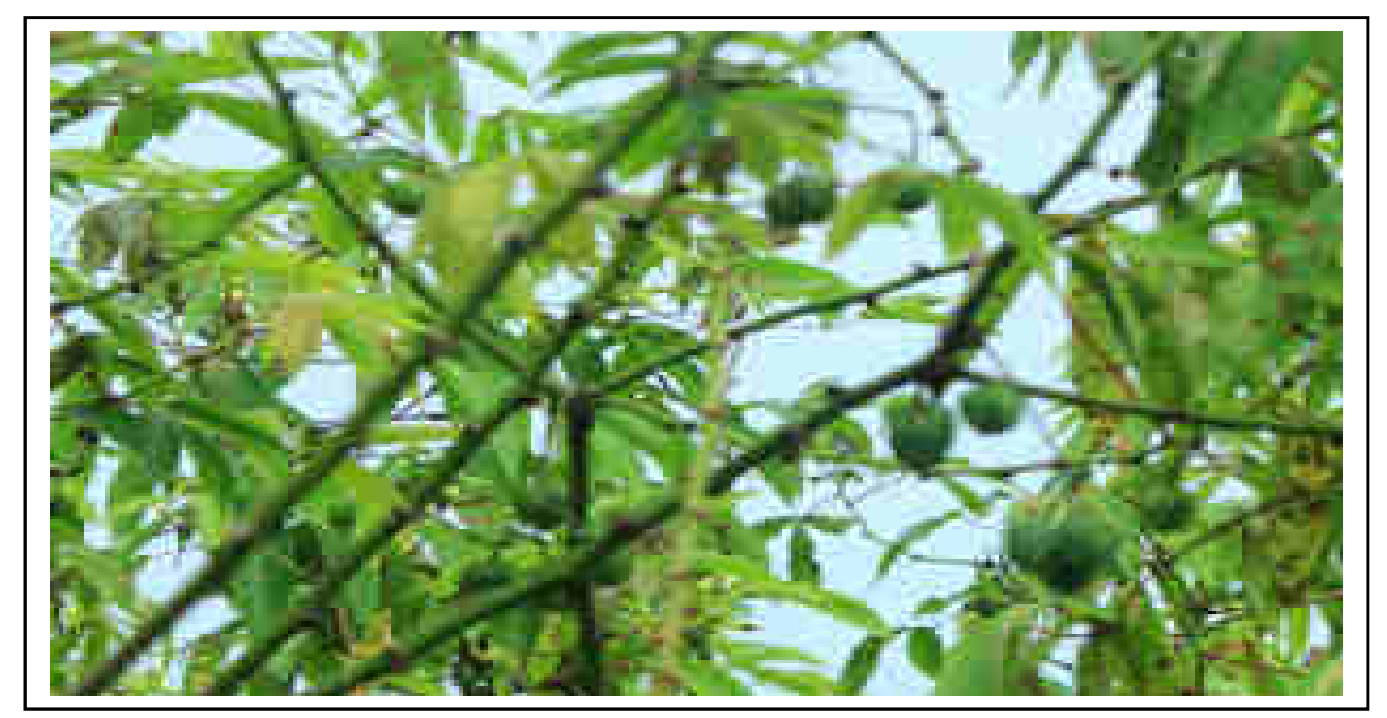

Gambar 4. Ubi kayu (M. esculenta)

Figure 4. Cassava (M. esculenta)

\section{Sengon (P. falcataria L.)}

Sengon dikenal masyarakat suku Dawan Fatuleu Tengah dengan sebutan angka'i (Gambar 5). Tumbuhan ini biasanya ditemukan di daerah hutan pegunungan. Pohon sengon memiliki banyak manfaat bagi masyarakat setempat, yaitu selain kayunya dimanfaatkan sebagai bahan bangunan, daunnya dijadikan sebagai pupuk dengan cara dikeringkan dan disimpan di sekeliling tanaman yang dipupuk. Kulit pohonnya digunakan warga sebagai pestisida untuk mengatasi hama di persawahan, dengan cara kulit pohon dimemarkan dan direndam selama satu malam, dan air rendaman disemprotkan pada padi. Masyarakat setempat percaya bahwa kulit batang sengon mengandung racun yang dapat mematikan hama. Menurut King et al., (2013) serbuk kayu sengon mengandung senyawa aktif seperti saponin, anthraquinon, fenol, flavonoid, alkaloid, tannin, sterol, dan triterpenoid. Ekstrak serbuk kayu sengon 
diketahui memiliki efek mortalitas terhadap imago Hypothenemus hampei (Purwatiningsih, 2019). Senyawa-senyawa aktif pada batang sengon juga diketahui mampu membuat tanaman sengon lebih resisten terhadap penyakit gall rust yang diakibatkan oleh jamur Uromycladium falcatarium (Rahmawati et al., 2019).

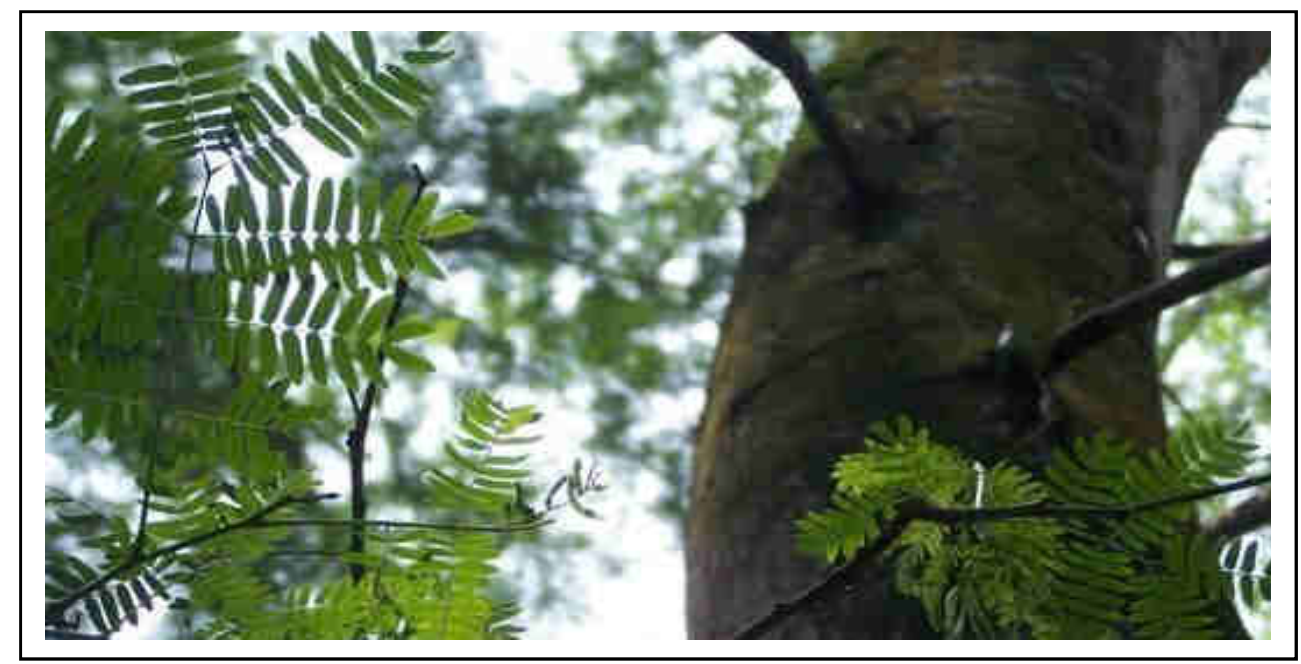

Gambar 5. Sengon (P. falcataria)

Figure 5. Sengon (P. falcataria)

\section{Ginje (T. peruviana)}

Tanaman ginje dikenal masyarakat suku Dawan Fatuleu Tengah dengan sebutan tun molo atau suf molo (Gambar 6). Tun molo dalam bahasa dawan Fatuleu, artinya bunga kuning. Tanaman ginje menghasilkan getah berwarna putih susu dan sangat beracun yang dapat mengakibatkan keracunan serius pada manusia. Hal ini sesuai pernyataan Langford \& Boor (1996) yang menyebutkan bahwa getah ginje mengandung glikosida kardiak yang beracun bagi otot jantung dan sistem saraf autonomic. Buah ginje juga diyakini masyarakat suku Dawan Fatuleu Tengah mengandung racun. Orang yang terkena racun ginje bisa mengalami keracunan yang serius bahkan bisa menyebabkan kematian.

Masyarakat suku Dawan Fatuleu Tengah memanfaatkan efek racun ginje untuk menyerang musuh. Berbeda dengan suku Dawan Fatuleu Tengah, di Asia Selatan seperti di Sri Lanka dilaporkan bahwa biji ginje banyak digunakan untuk tujuan bunuh diri dengan tingkat fatalitas 4-10\% (Bandara et al., 2010; Eddleston et al., 2008). Keracunan ginje yang serius akan menginduksi gangguan irama jantung yang berhubungan dengan konsentrasi glikosida kardiak yang tinggi dan hiperkalaemia (Eddleton et al., 2000). Seluruh bagian tanaman ginje mengandung glikosida kardiak, namun yang terbanyak ada pada kulit biji, diikuti berturut-turut daun, buah dan getah (Saravanapavananthan \& Ganeshamoorthy, 1988). Senyawa glikosida kardiak yang ditemukan dalam tanaman ginje antara lain thevetin $a$, thevetin $b$, thevetoxin, neriifolin, peruvoside, dan ruvoside (Langford \& Boor, 1996). Menurut Bandara (2010) keracunan senyawa glikosida kardiak dapat ditangani dengan pemberian arang aktif sebagai bentuk dekontaminasi gastrointestinal, untuk mengikat 
racun di perut dan mengurangi penyerapan racun oleh tubuh (Bandara, 2010).

Masyarakat suku Dawan Fatuleu Tengah ternyata juga memanfaatkan bunga ginje sebagai rempah-rempah, walaupun terdapat laporan bahwa bunga ginje juga mengandung racun.
Ginje selain digunakan sebagai racun ternyata juga dimanfaatkan oleh masyarakat suku Dayak sebagai bahan obat untuk anti bengkak dan infeksi kulit (Jannah \& Ridwan, 2013), pemanfaatannya digunakan sebagai obat luar.

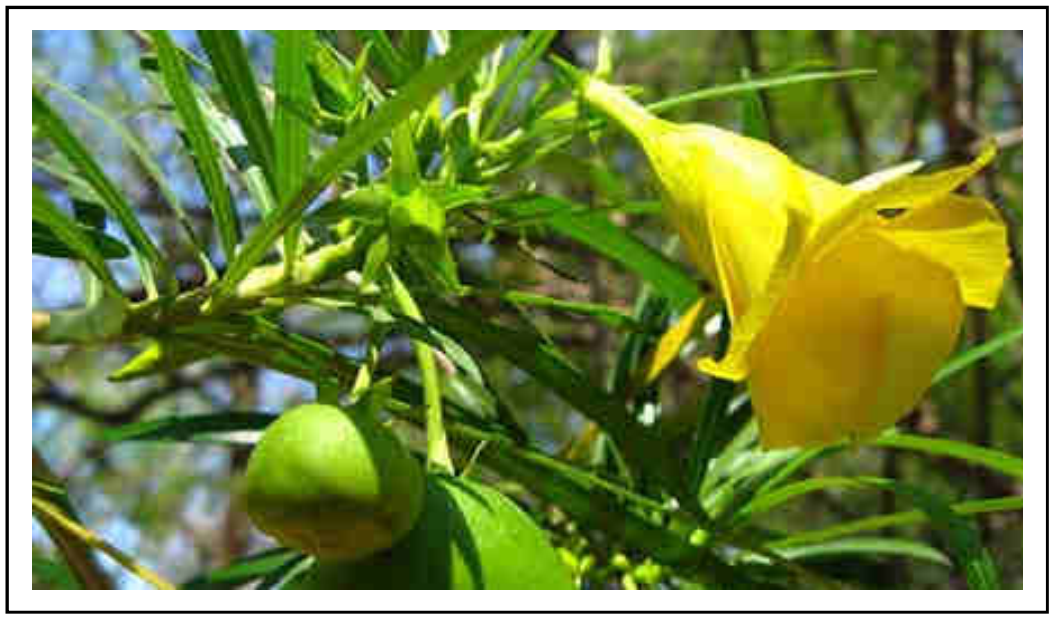

Gambar 6. Ginje (Thevetia peruviana) Figure 6. Yellow Oleander (Thevetia peruviana)

\section{Kecubung (D. metel L.)}

Kecubung dikenal masyarakat suku Dawan Fatuleu Tengah dengan nama ko'mah (Gambar 7). Masyarakat suku Dawan Fatuleu Tengah menggunakan daun kecubung ini sebagai racun, yaitu dengan cara mengoleskan getah daun pada bagian bawah batang bambu yang diisi dengan tuak aren. Dengan demikian, musuh yang meminum tuak tersebut akan keracunan dan mati dalam waktu singkat. Semua bagian tanaman kecubung diketahui memiliki senyawa aktif yang dapat menjadi racun. Pada daun kecubung mengandung senyawa kimia alkaloid, saponin, flavonoida, dan fenol (Alabri et al., 2014). Tijani et al. (2015) mendeteksi kehadiran alkaloid, senyawa psikoaktif atropin dan skolopamin pada ekstrak daun kecubung, yang menyebabkan gangguan pengurangan motorik dan mengurangi daya ingat hewan uji mencit.

Gejala keracunan yang biasanya timbul terutama akibat zat atropin dan skolopamin adalah mulut kering, sembelit, sensitif terhadap cahaya, dan sakit mata. Esktrak daun kecubung juga dilaporkan memiliki efek toksik terhadap hati, ginjal, dan saluran percernaan hewan uji mencit (Alebiowu et al., 2007).

Beberapa penelitian juga telah menemukan aktivitas menghambat dan mematikan ekstrak daun kecubung terhadap serangga, bakteri maupun fungi, sehingga dapat dijadikan sebagai biopestisida dan mikrofungi alami (Martini et al., 2018; Alabri et al., 2014). Selain memanfaatkan akar dan batang sebagai racun, masyarakat suku Dawan Fatuleu Tengah memanfaatkan daun kecubung untuk menyembuhkan penyakit kulit seperti panu dan kudis. 


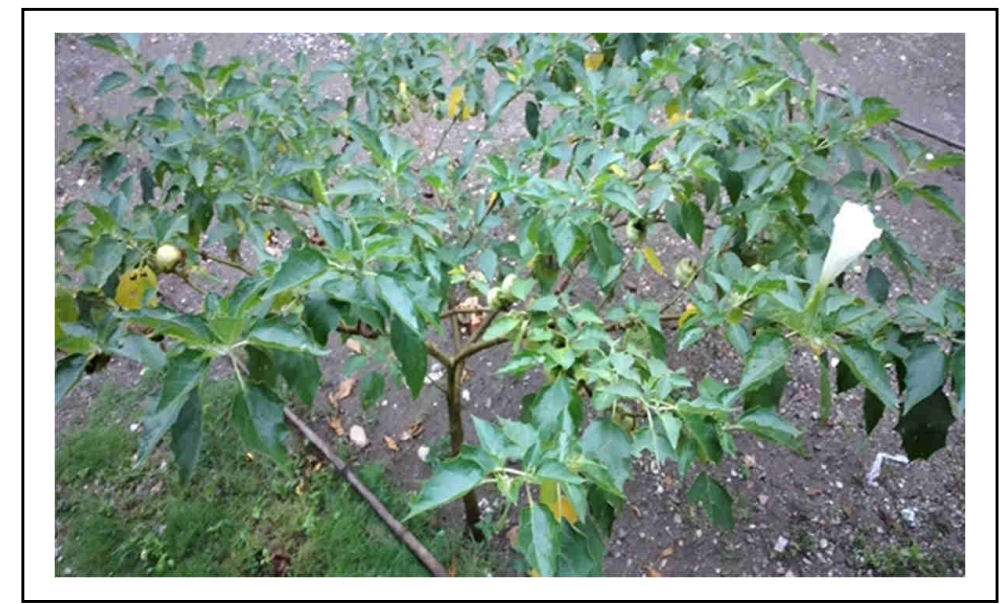

Gambar 7. Kecubung (D. metel)

Figure 7. Indian Thornapple (D. metel)

\section{Ceremai (P. acidus L.)}

Masyarakat suku Dawan Fatuleu Tengah mengenal tanaman ceremai dengan nama umum cermelek atau dalam bahasa Dawan Fatuleu salmelak (Gambar 8). Buah ceremai biasanya dimanfaatkan masyarakat desa sebagai bahan cemilan atau manisan. Selain itu ceremai juga dapat digunakan sebagai obat tradisional. Bagian akar mengandung racun yang sangat berbahaya, bahkan bisa menyebabkan kematian jika tidak ditangani secara tepat dan cepat. Racun dari akar ceremai digunakan oleh masyarakat suku Dawan Fatuleu Tengah untuk menyerang musuh. Menurut Zulfalina (2018), akar ceremai mengandung saponin, asam glutamat, zat samak, dan zat beracun. Ekstrak akar ceremai mengandung phyllanthusol $\mathrm{A}$ and B yang memiliki aktivitas sitotoksik (Durham et al., 2002; Vongvanich et al., 2000). Bagian daun, batang dan biji ceremai mengandung banyak senyawa aktif yang memiliki aktivitas anti imflamasi, antioksidan, juga diuji sebagai biopestisida terhadap serangga seperti pada nyamuk Aedes aegypti (Pratiwi et al., 2031; Chakraborty et al., 2012).

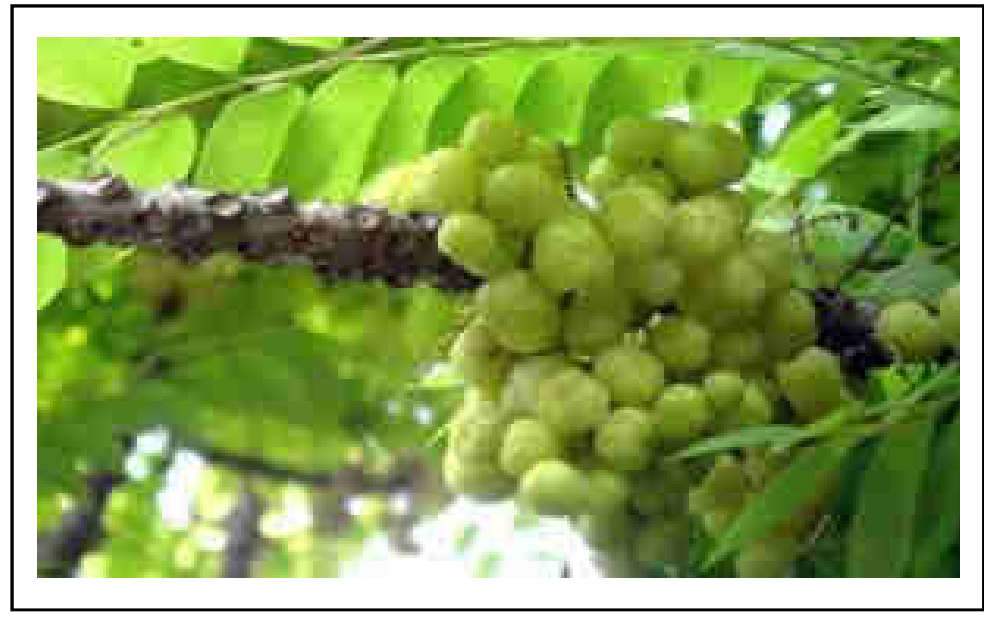

Gambar 8. Ceremai (P. acidus) Figure 8. Indian-gooseberry (P. acidus) 


\section{Biduri (C. gigantea L.)}

Tanaman biduri atau juga sering disebut koleng susu (Gambar 9), dalam masyarakat Desa Nunsaen sering disebut A'ttoh dapat dijadikan racun atau pestisida bagi hewan yang dianggap sebagai hewan pengganggu. Getahnya yang beracun apabila dicampurkan dengan makanan kemudian dikonsumsi secara langsung maka dapat menyebabkan muntah-muntah, kejang serta dapat menyebabkan kematian. Getah biduri diketahui juga digunakan sebagai racun pada panah suku di Afrika (Kanchan \& Atreyu, 2016). Sanyal et al. (2016) melaporkan hal yang sedikit berbeda bahwa getah biduri tidak menimbulkan efek toksisitas sub-akut terhadap organ dan berat tumbuh mencit (dosis $1000 \mathrm{mg} / \mathrm{kg}$ berat mencit selama 28 hari uji), sehingga dapat dipertimbangkan sebagai agen terapi fitomedikal. Getah biduri mengandung senyawa fitokimia seperti flavonol, glikosida, uscharidin, calotropin, frugoside, calotroposides A to $\mathrm{G}$ (Sanyal et al., 2016). Uscharidin dan beberapa senyawa lain pada daun biduri berhasil diketahui efek toksisitasnya terhadap sel kanker sehingga dapat digunakan sebagai bahan obat setelah melalui tahan pengujian selanjutnya (Jacinto et al., 2011).

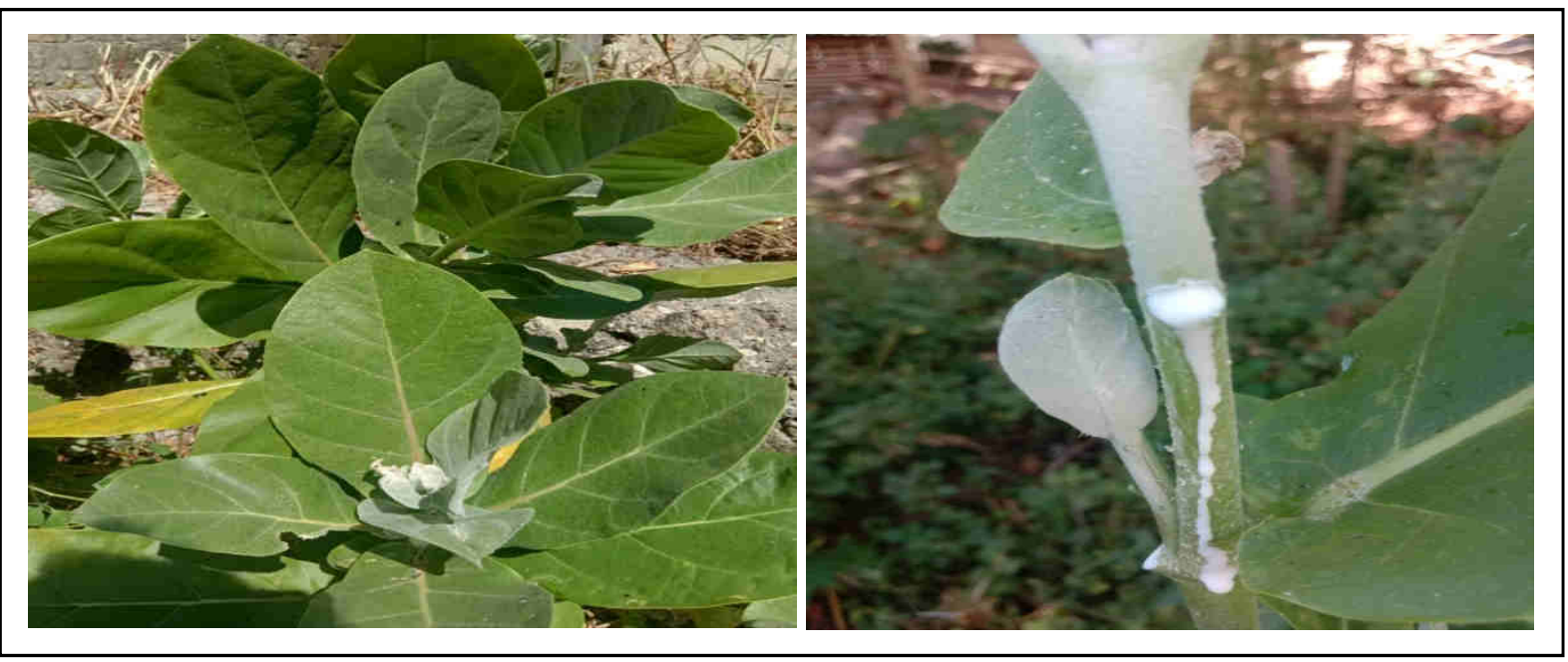

Gambar 9. Biduri (C. gigantea) dan getah biduri Figure 9. Biduri plants (C. gigantea) and biduri gum

\section{KESIMPULAN}

Jenis tumbuhan beracun yang dimanfaatkan oleh suku Dawan Fatuleu Tengah sebanyak 8 spesies dari 6 famili. Delapan spesies tumbuhan yang mengandung racun tersebut yaitu kacang arbila hutan $(P$. lonatus L.), akar tuba (D. elliptica L.), ubi kayu (M. esculent), sengon ( $P$. faltacataria $\mathrm{L})$, ginje ( $T$. peruvianan), kecubung $(D$. metel $\mathrm{L})$, ceremai $(P$. acidus $\mathrm{L})$, dan koleng susu (C. gigantean $\mathrm{L})$.
Masyarakat suku Dawan Fatuleu Tengah memanfaatkan tumbuhan beracun tersebut untuk meracuni ikan di sungai, dikonsumsi, sebagai pestisida alami/racun bagi organisme pengganggu tanaman, membunuh serangga vektor penyakit, dan tujuan lainnya, yaitu menyerang musuh atau mempertahankan diri dari serangan musuh. 


\section{UCAPAN TERIMA KASIH}

Ucapan terima kasih disampaikan kepada Kepala Desa Nunsaen dan Desa Nonbaun, Kecamatan Fatuleu Tengah, serta masyarakat desa tersebut yang telah membantu dalam pengambilan data penelitian ini. Terima kasih disampaikan pula kepada Felix L. Gole yang telah membantu dalam pembuatan peta lokasi penelitian.

\section{KONTRIBUSI PENULIS}

Konseptualisasi: Anriyani I. Pinat, Arnold Ch. Hendrik, Apriliana Ballo, Analisis data: Anriyani I. Pinat, Arnold Ch. Hendrik, penulisan naskah: Anriyani Pinat, Apriliana Ballo, Arnold Ch Hendrik, dan pengeditan naskah: Arnold Ch. Hendrik.

\section{DAFTAR PUSTAKA}

Alabri, T.H.A., Al Musalami, A.H.S., Hossain, M.A., \& Mohammad, A. (2014). Comparative study of phytochemical screening, antioxidant, and antimicrobial capacities of fresh and dry leaves crude plant extracts of Datura metel L. Journal of King Saud University-Science, 26, 237243.

doi: doi.org/10.1016/j.jksus.2013.07.002.

Alebiowu, G., Femi-Oyewo, M.N., Elujoba, A.A., \& Ojo, O.S. (2007). Toxicity studies on Datura metel L. with reference to official stramonium. Journal of Herbal Pharmacotherapy, 7(1), 1-12. doi:10.1300/J157v07n01_01

Ariani, L.N., Estiasih, T., \& Martati, E. 2017. Karakteristik sifat fisiko kimia ubi kayu berbasis kadar sianida. Jurnal Teknologi Pertanian, 18 (2), 119-128. doi: http://dx.doi.org/10.21776/ub.jtp.2017.01 8.02.12.

Asmaliyah, Wati, E.A., Utami, S., Mulyadi, K.,
Yudhistira., \& Sari, F.W. (2010). Pengenalan tumbuhan penghasil pestisida nabati dan pemanfaatannya secara tradisional. Palembang: Kementrian Kehutanan. Badan Penelitian Dan Pengembangan Kehutanan. Pusat Penelitian Dan Pengembangan Produktivitas Hutan.

Ballhorn, D.J., Lieberei, R., \& Ganzhorn, J.U. (2005). Plant cyanogenesis of Phaseolus lunatus and its relevance for herbivore plant interaction: The importance of quantitative data. Journal of Chemical Ecology, 31(7), 1445-1473. doi: 10.1007/s10886-005-5791-2.

Balhorn, D.J., Kautz, S., Heil, M., \& Hegeman, A.D. (2009) Cyanogenesis of wild lima bean (Phaseolus lunatus L.) is an efficient direct defence in nature. PLoS ONE, 4(5), 1-7. doi:10.1371/journal.pone.0005450.

Bandara, V., Weinstein, S.A., White, J., \& Eddleston, M. (2010). A review of the natural history, toxinology, diagnosis and clinical management of Nerium oleander (common oleander) and Thevetia peruviana (yellow oleander) poisoning. Toxicon, 56, 273-281. doi:10.1016/j.toxicon.2010.03.026.

Baudoin, J. P., 2006. Phaseolus lunatus L. Record from protabase. Brink, M. \& Belay, G. (Editors). Wageningen : PROTA (Plant Resources of Tropical Africa / Ressources végétales de l'Afrique tropicale),

Binawati, D.K., \& Amilah, S. (2013). Effect of cherry leaf (Muntinga calabora) bioinsecticides extract towards mortality of worm soil (Agrotis ipsilon) and armyworm (Spodoptera exiqua) on plant leek (Allium fistolum). Wahana, 61 (2), 
$52-57$.

Chakraborty, R., De, B., Devanna, N., \& Sen, S. (2012).Antiinflammatory, antinociceptive and antioxidant activities of Phyllanthus acidus L. extracts. Asian Pacific Journal of Tropical Biomedicine, S953-S961. doi:10.1016/S2221-1691(12)60343-8

Durham, D., Reid, R., Wangboonskul, J., \& Daodee, S. (2002) Extraction of phyllanthusols A and B from Phyllanthus acidus and analysis by capillary electrophoresis. Phytochemical Analysis, $13,358-362$.

Eddleston, M., Ariaratnam, C.A., Sjöström, L., Jayalath, S., Rajakanthan, K., Rajapakse, S., Colbert, D., \& Warrell, D.A. (2000). Acute yellow oleander (Thevetia peruviana) poisoning: cardiac arrhythmias, electrolyte disturbances and serum cardiac glycoside concentrations on presentation to hospital. Heart, 83, 301-306.

Eddleston, M., Juszczak, E., Buckley, N.A., Senarathna, L., Mohamed, F., Dissanayake, \& Warrell, D.A. (2008). Multiple-dose activated charcoal in acute self-poisoning: A randomised controlled trial. Lancet, 371, 579-587.

Fasuyi, A.O. (2005). Nutrient composition and processing effects on cassava leaf (Manihot esculenta Crantz) antinutrients. Pakistan Journal of Nutrition, 4, 37-42.

Ilmi, J., Dharmono, \& Hayani, N.I. (2015). Inventarisasi dan pemanfaatan tumbuhan beracun oleh masyarakat Dayak Bakumpai di Desa Simpang Arja, Kecamatan Rantau Badauh, Kabupaten Barito Kuala. Jurnal Wahana-Bio, 13, 93114.

Jacinto, S.D., Chuna, E.A.C., Montunoa, A.S.,
Shenb, C., Espinelic, D.L., \& Ragasac, C.Y. (2011). Cytotoxic cardenolide and sterols from Calotropis gigantea. Natural Product Communications, 6(6), 803-806.

Jannah, H., \& Ridwan. (2013). Pengobatan tradisional suku Sasak berbasis ilmiah di Kabupaten Lombok Barat. Jurnal Ilmiah Biologi "Bioscientist”, 1 (2), 116-125.

Kanchan, M.T., \& Atreyu M.A. (2016). Calotropis gigantea. Wilderness \& Environmental Medicine, 27, 350-351.

Kinansi, R.R., Handayani, S.W., Prastowo, D., \& Sudarno, A.O.Y. (2018). Efektivitas ekstrak etanol akar tuba (Derris elliptica) terhadap kematian Periplaneta Americana dengan metode spraying. Balaba, 14(2), 147-158.

doi: https://doi.org/10.22435/blb.v14i2.70.

King, M., Catranis, C., Soria, J.A., \& Leigh, M.B. (2013). Phytochemical and toxicological analysis of Albizia falcataria sawdust. International Wood Products Journal, 4:4, 232241, doi:10.1179/2042645312Y.0000000029

Langford, S.D., \& Boor, P.J., (1996). Oleander toxicity: An examination of human and animal toxic exposures. Toxicology, 109, 1-13. doi: 10.1016/0300-483x(95)03296-r.

Martini, M., Astriana, N., Yuliawati, S., Hestiningsih, R., Mawarni, A., \& Purwantisari, S. (2018). Keefektifan ekstrak daun kecubung (Datura metel L.) dalam menghambat penetasan dan siklus hidup Aedes aegypti L. Indonesian Journal of Entomology, 15(1), 50-56. doi: 10.5994/jei.15.1.50.

Montagnac, J.A., Davis, C.R., \& Tanumihardjo, S.A. (2008). Processing techniques to reduce toxicity and antinutrients of 
cassava for use as a staple food. Comprehensive Reviews in Food Science and Food Safety, 8, 17-27.

Noerwijati, K., \& Budiono, R. (2018). Mengenal senyawa HCN pada ubi kayu. Dalam O.D. Hajoeningtijas (Eds). Prosiding Seminar Nasional Optimalisasi Sumberdaya Lokal Untuk Mewujudkan Kedaulatan Pangan (hal 172-182).

Okigbo, BN. (1980). Nutritional implication of projects giving high priority of the production of staples of low nutritive quality. In the case of cassava (Manihont esculenta Crantz) in the humid tropics West Africa. Food Nutrition Bulletin. 2,110.

Pratiwi, Y.C., Haryono, T., \& Rahayu, Y.S. (2013). Efektivitas ekstrak daun ceremai (Phyllanthus acidus) terhadap mortalitas larva Aedes aegypti. LenteraBio, 2(3), 197-201.

Purwatiningsih., Mandasari, F.P., \& Fajariyah, S. (2019). Toksisitas ekstrak n-heksana serbuk gergaji kayu sengon (Albizia falcataria L. Forberg) terhadap mortalitas serangga penggerek buah kopi (Hypothenemus hampei Ferr.) (Scolytidae: Coleoptera). Biotropic The Journal Of Tropical Biology, 3(1), 39-48.

Puspita, D., Palimbong, S., Toy, B., \& Notosoedarmo, S. (2017). Identifikasi legum lokal di Pulau Timor yang berpotensi dalam pengembangan inovasi pangan lokal. Dalam Wahyuningrat dan Supriyanto (Eds). Prosiding Seminar Nasional 'Pengembangan Sumber Daya Perdesaan dan Kearifan Lokal Berkelanjutan VII' (hal : 324-335)

Putri, A.P., Manaf, S., \& Salim, M. (2019). Uji efektivitas ekstrak daun oleander (Nerium oleander L.) sebagai biolarvasida terhadap Aedes aegypti. Spirakel, 11 (2), 44-52.doi:

https://doi.org/10.22435/spirakel.v11i2.1 836.

Rahmawati, D., Khumaida, N., \& Siregar, U.J. (2019). Morphological and phytochemical characterization of susceptible and resistant sengon (Falcataria moluccana) tree to gall rust disease. Biodiversitas, 20(3), 907-913. doi: 10.13057/biodiv/d200340.

Sae-Yun, A., Ovatlarnporn, C., Itharat, A., \& Wiwattanapatapee, R. (2006). Extraction of rotenone from Derris elliptica and Derris malaccensis by pressurized liquid extraction compared with maceration. Journal of Chromatography A, 1125 (2), 172-176. doi:10.1016/j.chroma.2006.05.075

Salaki, C.L., \& Pelealu, J. (2012). Pemanfaatan Baringtonia asiatica dan Annona muricata terhadap serangga vektor penyakit pada tanaman cabai. Eugenia, 18(1), 22-28.

Sayono., Permatasari, A., \& Sumanto, D. (2019). The effectiveness of Derris elliptica (Wall.) Benth. root extract against temephos-resistant Aedes aegypti larvae. IOP Conf. Series: Earth and Environmental Science, 292, 1-7. doi:10.1088/1755-1315/292/1/012052.

Sanyal S, Maity P, Pradhan A, Bepari, M., Dey, S.K., Roy T., \& Choudhurym S. M. (2016). Sub-acute toxicity study of Calotropisgigantea latex extracts in male Swiss albino mice. Toxicology and ForensicMedicine Journal, 1(2), 54-64. doi: 10.17140/TFMOJ-1-109.

Saravanapavananthan, N., \& Ganeshamoorthy, 
J., (1988). Yellow oleander poisoning: A study of 170 cases. Forensic Science International, 36, 247-250.

Setiawati ,W,R. Murtiningsih, N. Gunaeni \& T. Rubiati. (2008). Tumbuhan bahan peptisida nabati dan cara pembuatannya untuk pengendalian organisme pengganggu tumbuhan (OPT). Bandung : Balai Penelitian Tanaman Sayuran.

Sumarmin, R. (2016). Uji in vitro ekstrak akar tuba (Derris elliptica L.) terhadap viabilitas tetas telur ikan mas (Cyprinus carpio L.). Dalam I.R Aziz, M. Mashri, Hafsan, F. Nur, B.F. Wahidah, \& Hasyimudin. Seminar Nasional from Basic Science to Comprehensive Education (hal : 237-243).

Taofik, M., Yulianti, E., Barizi, A., \& Hayati, E.K. (2010) Isolasi dan identifikasi senyawa aktif ekstrak air daun paitan (Tithonia diversifolia) sebagai bahan insektisida botani untuk pengendalian hama tungau Eriophyidae. Alchemy. 2 (1), 104-157.

Tijani, A.Y., Eyineyi, U.G., Ibrahim, J.A., \& Okhale, S.E. (2015). Neuro-toxicological impacts of Datura Metel Linn. (Family: Solanaceae) leaves extract in mice. The Journal of Neurobehavioral Sciences, 2(3),
1-5. doi: 10.5455/JNBS.1443629662.

Utami, S. \& Haneda, N.F. (2010). Pemanfaatan etnobotani dari hutan tropis Bengkulu sebagai pestisida nabati. Jurnal Manajemen Hutan Tropis, 16 (3), 143-147. Doi: https://doi.org/10.7226/jtfm.16.3.\%p

Vongvanich, N., Kittakoop, P., Kramyu, J., Tanticharoen, M., \& Thebtaranonth, Y. (2000). Phyllanthusols A and B, cytotoxic norbisabolane glycolsides from Phyllanthus acidus Skeels. The Journal of Organic Chemistry, 25, 5420-5423.

Widyastuti, R., Susanti, D., \& Wijayanti, R. (2018). Toksisitas dan repelensi ekstrak daun titonia (Tithonia diversifolia) terhadap kutu putih (Aleurodicus dugesii) pada tanaman iler. Buletin Penelitian Tanaman Rempah dan Obat, 29 (1), 1 - 8.

Yuningsih. (2009). Perlakuan penurunan kandungan sianida ubi kayu untuk pakan ternak. Penelitian Pertanian Tanaman Pangan, 28(1), 58-61.

Zubairi, S.A., Sarmidi, M.R., \& Aziz, R.A. (2014). A preliminary study of rotenone exhaustive extraction kinetic from Derris elliptica dried roots using normal soaking extraction (NSE) method. Advances in Environmental Biology, 8(4), 910-915. 